\title{
EVALUATION OF CYTOTOXIC ACTIVITY OF ETHYL ACETATE EXTRACT OF PIGMENT FROM PSEUDOMONAS AERUGINOSA
}

\author{
GEETANJALI R KAMBLE ${ }^{1}$, HIREMATH SV ${ }^{2}$, HIREMATH MB ${ }^{3 *}$ \\ ${ }^{1}$ Post-Graduate Department of Studies in Biotechnology and Microbiology, Karnatak University, Dharwad (Karnataka), India. Department \\ of Biotechnology and Microbiology, P.C. Jabin Science College, Hubballi (Karnataka), India. ${ }^{2}$ Post-Graduate Department of Studies \\ in Biotechnology and Microbiology, Karnatak University, Dharwad (Karnataka), India. ${ }^{3}$ Post-Graduate Department of Studies in \\ Biotechnology and Microbiology, Karnatak University, Dharwad (Karnataka), India. *Email: murigendra@gmail.com
}

Received: 20 February 2020, Revised and Accepted: 15 April 2020

\section{ABSTRACT}

Objective: Bacterial pigments have promising applications in food, cosmetics, textile, and therapeutics. Pigments from microbial origin are stable, safer, cost effective, easy production, and extraction and thus preferred over other natural sources. Under this backdrop, isolation and characterization of pigment-producing bacteria and analysis of bioactivity of the pigment were the aim of the study. From the literature studies, the pigment production was found to be influenced by various physical factors which directed the study toward optimization of physical parameters for pigment production.

Methods: Isolation of pigment-producing bacteria from water sample, cultural, and microscopic identification was done as per the standard protocol. Extraction of pigment by solvent extraction was carried out and its antibacterial and cytotoxic activity was assayed.

Results: Molecular characterization of the bacteria resembled the query sequence of the isolate to 99\% with Pseudomonas aeruginosa strain. Extraction of pigment by solvent extraction method resulted in crude pigment extract with antibacterial activity against Gram-negative bacteria (17 mm zone of inhibition) at $100 \mu \mathrm{g} / \mathrm{ml}$ concentration. Pigment showed dose-dependent inhibition on proliferation of HeLa cells at the concentration of $345.83 \mu \mathrm{g} / \mathrm{mL}$.

Conclusion: From the above results, it was evident that the pigment extracted from the bacterial isolate Pseudomonas aeruginosa strain JBT18N was therapeutically potential.

Keywords: Pigment, Antibacterial, Anticancer, MTT Assay.

(C) 2020 The Authors. Published by Innovare Academic Sciences Pvt Ltd. This is an open access article under the CC BY license (http://creativecommons. org/licenses/by/4. 0/) DOI: http://dx.doi.org/10.22159/ajpcr.2020.v13i6.37217

\section{INTRODUCTION}

Since a decade, there was a robust consumer call for more natural merchandise in therapeutics. Discovery of newer molecule to be used as chemotherapeutic agent has become the need of time [1]. The use of microorganisms for biological reason has end up an effective opportunity to control pathogens [2]. Bioactive compounds because of their safer and extensive applications are preferred over artificial one and thus have augmented inclination closer to substitution of artificial compounds with biological origin. Among natural sources (plants, animals, and insects), microbes are potentially suitable alternatives for the bioactive compounds [3]. Many microbial secondary metabolites are reported with wide range of applications in areas such as food, textile, cosmetics, leather, and pharmaceuticals [4-7]. Numerous plants and microorganisms are known to produce natural colored compounds such as carotenoids, chlorophyll, and anthocyanins [8]. Although the flora produces pigments, it has some drawbacks such as instability toward temperature, light, and non-availability throughout the 12 months. Thus, microbial pigments prove to be advantageous and preferred choice for their applications in various fields [9]. This colorful microbial world has attracted many researchers to explore them for human applications as in textile industries, cosmetics, pharmaceuticals, food industries, and medical $[10,11]$. Microbial pigments (prodigiosin, astaxanthin, carotenoids, and violacein) are one such metabolites exhibiting multifacet role in medical due to their various biological activities such as antidiabetic, anti-aging, antioxidant, anticancer, and immunosuppressive agents [12]. The interest of researchers toward usage of natural resources for pigments is due to their safe application, simple methods of extraction, cost-effective production, and eco-friendly nature. Many microbial pigments are commercially available as carotenoids, melanin, quinones, violacein, anthraquinone, prodigiosins, chlorophyll, flavins, monascin, etc. [13]. Diverse group of pigment-producing microorganisms is found in natural environment. Thus, natural aquatic bodies serve as diverse bowl of versatile microbes which can be exploited for the production of various bioactive compounds [14-16].

\section{MATERIALS AND METHODS}

Bacteriological media from HiMedia Pvt. Ltd. were used for the isolation and mass culture of the isolates. Gram staining kit, solvents, and chemicals for biochemical analysis were used from SRL, E. Merck, India.

Water sample for the study was collected from industrial effluents of Dandeli Paper Mills, Uttar Kannada district of Karnataka [17]. A 500 ml of water was collected in sterile plastic bottles, kept in ice box to restrict the microbial growth. $\mathrm{pH}$ of water was checked at the sampling point by $\mathrm{pH}$ paper and was transported in controlled conditions to laboratory for further analysis $[18,19]$. Water sample was serially diluted in saline and plated onto nutrient agar, Mueller-Hinton media, and Zobell Marine

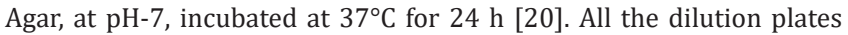
from all media were examined for the pigment-producing bacterial isolates. Pigmented bacterial isolates were pure cultured and one set was preserved in refrigerator for further studies [7]. Mass culture was done with $500 \mathrm{ml}$ nutrient broth in four flasks. The flasks after inoculation were kept for incubation at $37^{\circ} \mathrm{C}$ for $24 \mathrm{~h}$.

\section{Optimization of parameters}

Optimization of fermentation methods is an essential approach needed for high stage production of valuable fermentative products. Medium optimization is one in all the important techniques for purchasing maximum pigment yield and it involves numerous elements which include medium additives, operating conditions, $\mathrm{pH}$, temperature, aeration 
and agitation, and so on [21]. The bacterial isolate in the study was also observed for its pigment production at varied physical parameters [22].

The experiment was set up in sets for parameters such as $\mathrm{pH}$, temperature, incubation time, and agitation.

1. The sterile nutrient broth with $\mathrm{pH} 7,8,9,10,11$, and 12 was inoculated with the bacteria culture and incubated at $37^{\circ} \mathrm{C}$.

2. The sterile nutrient broth with $\mathrm{pH} 7$ was inoculated with the bacteria culture and incubated at $-4^{\circ} \mathrm{C}, 4^{\circ} \mathrm{C}, 37^{\circ} \mathrm{C}$, RT, and $40^{\circ} \mathrm{C}$ in static condition.

3. The sterile nutrient broth with $\mathrm{pH} 7,8,9,10,11$, and 12 was inoculated with the bacteria culture and incubated at RT in rotary shaker and in static condition.

4. The sterile nutrient broth with $\mathrm{pH} 7,8,9,10,11$, and 12 was inoculated with the bacteria culture and incubated at $37^{\circ} \mathrm{C}$ for $24 \mathrm{~h}$, $48 \mathrm{~h}, 98 \mathrm{~h}$, and $120 \mathrm{~h}$

\section{Identification of test organism}

The pigmented bacterial colonies from all dilutions were microscopically observed for Gram identification. Further, they were also observed for cultural characters as size, shape, color, elevation, margin, texture, opacity, consistency, motility, and endospore forming. To analyze the isolate at molecular level, 16s rRNA sequencing was carried out. The query sequence was blast to analyze the phylogenetic homology.

\section{Extraction of the crude pigment}

The bacterial broth was processed for the extraction of pigment by liquid-liquid extraction method using ethanol, methanol, and ethyl acetate solvents. Ethyl acetate was chosen as a solvent for extraction of the pigment due to its solubility in it. The incubated bacterial broth was centrifuged at $8000 \mathrm{rpm}$ for $10 \mathrm{~min}$. The colored supernatant was collected in a fresh tube and the cell pellet was discarded. The supernatant was treated with equal volume of ethyl acetate and the extract was collected by separating funnel and dried at room temperature [22]

\section{Antibacterial activity of pigment}

Pigment was assayed for its antibacterial activity against four human bacterial pathogens as follows:

1. Staphylococcus aureus - ATCC 25923/MCC 2408

2. Bacillus subtilis - ATCC 6633/MCC 2048

3. Pseudomonas aeruginosa - ATCC 27853/MCC 2080

4. Escherichia coli - ATCC 11775/MCC 2079 (T)

Petri plates containing $20 \mathrm{ml}$ nutrient agar were seeded using cotton swab with $24 \mathrm{~h}$ (old) culture of bacterial strains. Wells were cut $(8 \mathrm{~mm}$ diameter) and $50 \mu \mathrm{l}$ of different concentrations of test samples $(100$, 200 , and $400 \mu \mathrm{g} / \mathrm{ml})$ and standard ciprofloxacin $(100 \mu \mathrm{g} / \mathrm{ml})$ was added. The plates were then incubated at $37^{\circ} \mathrm{C}$ for $24 \mathrm{~h}$. The antibacterial activity was assayed by measuring the diameter of the inhibition zone formed around the well [23].

\section{MTT cell proliferating assay}

A $200 \mu \mathrm{l}$ cell suspension was seeded in a 96-well plate at required cell density $(10,000$ cells per well), without the test agent. The cells were allowed to grow for about $24 \mathrm{~h}$. Appropriate concentrations of the test agent were added. The plates were incubated for $24 \mathrm{~h}$ at $37^{\circ} \mathrm{C}$ in a $5 \%$ $\mathrm{CO}_{2}$ atmosphere. MTT reagent of $0.5 \mathrm{mg} / \mathrm{mL}$ concentration was added to the plates, wrapped with aluminum foil to avoid exposure to light and incubated for further $3 \mathrm{~h}$. The MTT reagent was replaced by $100 \mu \mathrm{l}$ of solubilization solution (DMSO). The absorbance was read on ELISA reader at $570 \mathrm{~nm}$ and $630 \mathrm{~nm}$ used as reference wavelength. The $\mathrm{IC}_{50}$ value was determined using linear regression equation, i.e.,, $\mathrm{Y}=\mathrm{Mx}+\mathrm{C}$. Here, $\mathrm{Y}=50, \mathrm{M}$ and $\mathrm{C}$ values were derived from the viability graph [24].

\section{RESULTS}

Isolation and identification of pigment-producing bacteria Out of all the bacterial colonies produced on all the media used for isolation, prominent blue-green color producing bacterial isolate was selected for the study. Colony characteristics were studied with microscopic observation of Gram staining and structural staining. The isolate was Gram-negative, non-spore-forming, and non-capsulated motile rods (Table 1). Results of biochemical tests revealed that the isolate was negative to indole, methyl red, and Voges-Proskauer, urease, and coagulase test and positive to citrate catalase and oxidase nitrate reduction test (Table 1).

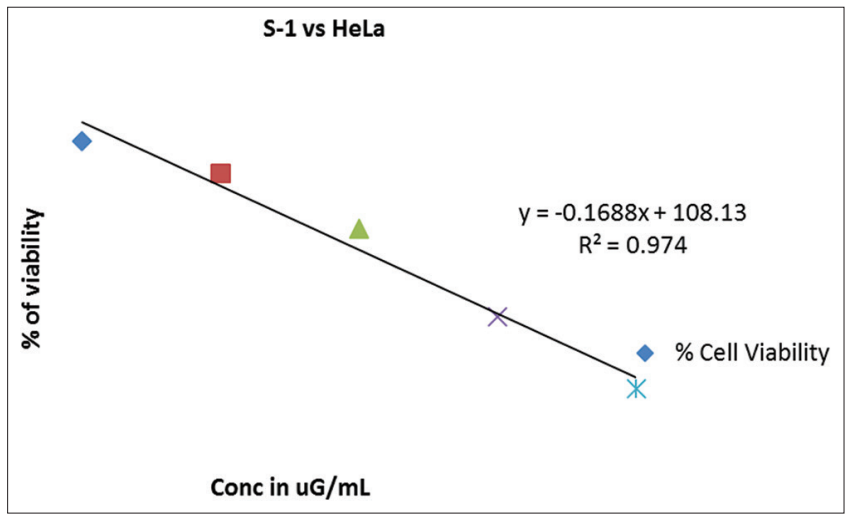

Graph 1: Percentage of cell viability with concentration

Table 1: Morphology and biochemical tests of bacterial isolate

\begin{tabular}{|c|c|c|c|}
\hline \multicolumn{2}{|c|}{ Colony morphology } & \multicolumn{2}{|c|}{ Biochemical analysis } \\
\hline Characteristics & Results & Tests & Results \\
\hline Shape & Rods & Indole & - ve \\
\hline Motility & Motile & MR & - ve \\
\hline Capsule & Non-capsulated & VP & -ve \\
\hline Endospore & Non-sporing & Citrate & + ve \\
\hline Flagella & Single flagella & Catalase & + ve \\
\hline gram staining & Gram negative & Oxidase & + ve \\
\hline \multirow[t]{3}{*}{ Pigment } & Positive (+ve) & Urease & -ve \\
\hline & & Nitrate reduction & + ve \\
\hline & & Coagulase & -ve \\
\hline
\end{tabular}

Table 2: Effect of different physical parameters on growth and pigment production by Pseudomonas aeruginosa. '+'no growth and no pigment production, ' + 'minimal growth with light pigmentation, ' ++ ' moderate growth with good pigmentation, '+++' luxuriant growth with intense pigment production

\begin{tabular}{|c|c|c|c|c|c|c|}
\hline \multirow[t]{2}{*}{ Parameter } & \multicolumn{6}{|c|}{ pH of media } \\
\hline & 7 & 8 & 9 & 10 & 11 & 12 \\
\hline Growth & ++ & + & ++ & + & + & + \\
\hline Pigmentation & +++ & ++ & +++ & ++ & +++ & + \\
\hline & \multicolumn{6}{|c|}{ Incubation temperature $\left({ }^{\circ} \mathrm{C}\right)$} \\
\hline & $-4^{\circ} \mathrm{C}$ & $4^{\circ} \mathrm{C}$ & RT & $37^{\circ} \mathrm{C}$ & $40^{\circ} \mathrm{C}$ & \\
\hline Growth & - & + & ++ & ++ & - & \\
\hline \multirow[t]{3}{*}{ Pigmentation } & - & + & ++ & ++ & - & \\
\hline & \multicolumn{6}{|c|}{ Incubation time (Hrs) } \\
\hline & 24 & 48 & 72 & 96 & 120 & \\
\hline Growth & + & + & + & + & + & \\
\hline \multirow[t]{3}{*}{ Pigmentation } & + & ++ & +++ & + & + & \\
\hline & \multicolumn{6}{|c|}{ Agitation } \\
\hline & \multicolumn{3}{|c|}{ Rotary shaker } & \multicolumn{3}{|c|}{ Static condition } \\
\hline Growth & \multicolumn{3}{|l|}{+} & \multicolumn{3}{|l|}{+} \\
\hline Pigmentation & \multicolumn{3}{|l|}{+++} & \multicolumn{3}{|l|}{++} \\
\hline
\end{tabular}


Optimization of growth conditions for pigment production

Out of all the media (nutrient broth, Mueller-Hinton media, and Zobell Marine broth) used in the study consistent and intense pigment production was observed in nutrient broth. Pseudomonas aeruginosa showed purple color pigment production within $24 \mathrm{~h}$ at room temperature on rotary shaker at $\mathrm{pH}-8$ and green color at $37^{\circ} \mathrm{C}$ in rotary shaker at pH-8. Further, the range of colors was observed at different $\mathrm{pH}$ from brown, purple, green, and blue at $\mathrm{pH}-7,8,9,10,11$, and 12 (Fig 1), (Table 2).

\section{Molecular characterization}

Identification of the bacterial isolate under study was done by 16s rRNA sequencing at NCCS, Pune. The BLAST result of the query sequence revealed the isolate to be $99 \%$ similar to Pseudomonas aeruginosa (Fig 2).

1 ctacacatgc aagtcgagcg gatgaaggga gcttgctcct ggattcagcg gcggacgggt 61 gagtaatgcc taggaatctg cctggtagtg ggggataacg tccggaaacg ggcgctaata 121 ccgcatacgt cctgagggag aaagtggggg atcttcggac ctcacgctat cagatgagcc 181 taggtcggat tagctagttg gtggggtaaa ggcctaccaa ggcgacgatc cgtaactggt 241 ctgagaggat gatcagtcac actggaactg agacacggtc cagactccta cgggaggcag 301 cagtggggaa tattggacaa tgggcgaaag cctgatccag ccatgccgcg tgtgtgaaga 361 aggtcttcgg attgtaaagc actttaagtt gggaggaagg gcagtaagtt aataccttgc 421 tgttttgacg ttaccaacag aataagcacc ggctaacttc gtgccagcag ccgcggtaat 481 acgaagggtg caagcgttaa tcggaattac tgggcgtaaa gcgegcgtag gtggttcagc 541 aagttggatg tgaaatcccc gggctcaacc tgggaactgc atccaaaact actgagctag 601 agtacggtag agggtggtgg aatttcctgt gtagcggtga aatgcgtaga tataggaagg 661 aacaccagtg gcgaaggcga ccacctggac tgatactgac actgaggtgc gaaagcgtgg 721 ggagcaaaca ggattagata ccctggtagt ccacgccgta aacgatgtcg actagccgtt 781 gggatccttg agatcttagt ggcgcagcta acgcgataag tcgaccgcct ggggagtacg 841 gccgcaaggt taaaactcaa atgaattgac gggggcccgc acaagcggtg gagcatgtgg $901 \mathrm{tttaattcga}$ agcaacgcga agaaccttac ctggccttga catgctgaga actttccaga

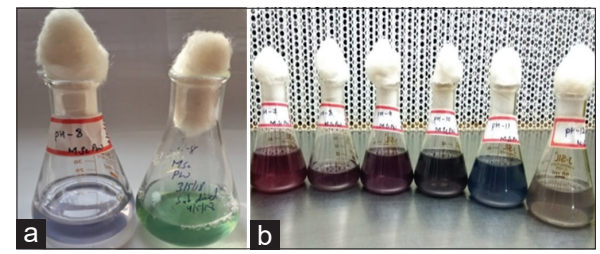

Fig. 1: (a) Violet and light green coloured pigment production by Pseudomonas aeruginosa in culture broth on rotary shaker at room temperature and $37 \mathrm{oC}$ respectively, (b) Range of coloured pigments in culture broth produced by Pseudomonas aeruginosa at $\mathrm{pH}-7,8,9,10,11$, and 12
961 gatggattgg tgccttcggg aactcagaca caggtgctgc atggctgtcg tcagctcgtg 1021 tcgtgagatg ttgggttaag tcccgtaacg agcgcaaccc ttgtccttag ttaccagcac 1081 ctcgggtggg cactctaagg agactgccgg tgacaaaccg gaggaaggtg gggatgacgt 1141 caagtcatca tggcccttac ggccagggct acacacgtgc tacaatggtc ggtacaaagg 1201 gttgccaagc cgcgaggtgg agctaatccc ataaaaccga tcgtagtccg gatcgcagtc 1261 tgcaactcga ctgcgtgaag tcggaatcgc tagtaatcgt gaatcagaat gtcacggtga 1321 atacgttccc gggccttgta cacaccgccc gtcacaccat gggagtgggt tgctccagaa 1381 gtagctagtc taaccgcaag ggggacggta ccacgga

\section{Antibacterial activity of crude pigment}

Crude pigment extracts in ethyl acetate from the bacterial isolate Pseudomonas aeruginosa JBT18N were tested for its antibacterial activity against four human bacterial pathogens. A $17 \mathrm{~mm}$ zone of inhibition was observed only against Escherichia coli - ATCC 11775/MCC 2079 (T) at $100 \mu \mathrm{g} / \mathrm{ml}$ concentration with positive control of $100 \mu \mathrm{g} / \mathrm{ml}$ standard ciprofloxacin antibiotic (Fig 3), (Table 3).

\section{Anticancer activity of crude pigment extract}

MTT assay of crude pigment extract from the bacterial isolate Pseudomonas aeruginosa JBT18N was tested on HeLa cells with $\mathrm{IC}_{50}$ concentrations at $345.83 \mu \mathrm{g} / \mathrm{mL}$ ( Graph 1).

\section{DISCUSSION}

Cancer chemoprevention employs natural or synthetic compounds to prevent, arrest, or cease carcinogenesis [25]. The use of microbial metabolites as a remedy of most cancers has been utilized since long time [26]. Since the past 10 years, compounds derived from bacteria were tested for their antibacterial and anticancer activity [27]. This includes the use of naturally occurring microbial biomass, bacterial strains to be engineered for the expression of desired genes. Advanced and novel approach includes the use of bacteria or bacterial metabolites as proteins, enzymes, and pigments that can cause inhibition of growth or the apoptosis of tumor cells [28]. In this regard, natural pigments can be extracted from plants, insects, animals, and microbes (fungi, bacteria, and actinomycetes). Among all the bacterial pigments are preferred over the other natural sources for their easy isolation, cost-effective substrates, purification techniques, diverse range of pigment production, and safer applications [29].

In the present study, the pigment production was affected by many physical factors such as temperature, $\mathrm{pH}$, light, agitation, and incubation time. Intense and consistent pigment production was recorded at $37^{\circ} \mathrm{C}$, $\mathrm{pH} 10.8$, and incubation for $72 \mathrm{~h}$ with agitation. The optimum growth of bacterial isolate TM and production of carotenoid at $37^{\circ} \mathrm{C}$ with $\mathrm{pH} 7.2$ after $144 \mathrm{~h}$ of incubation with agitation in a media supplemented with $1 \%$ yeast extract, $0.75 \%$ casamino acids, $25 \% \mathrm{NaCl}, 4 \% \mathrm{MgSO} 4$, and

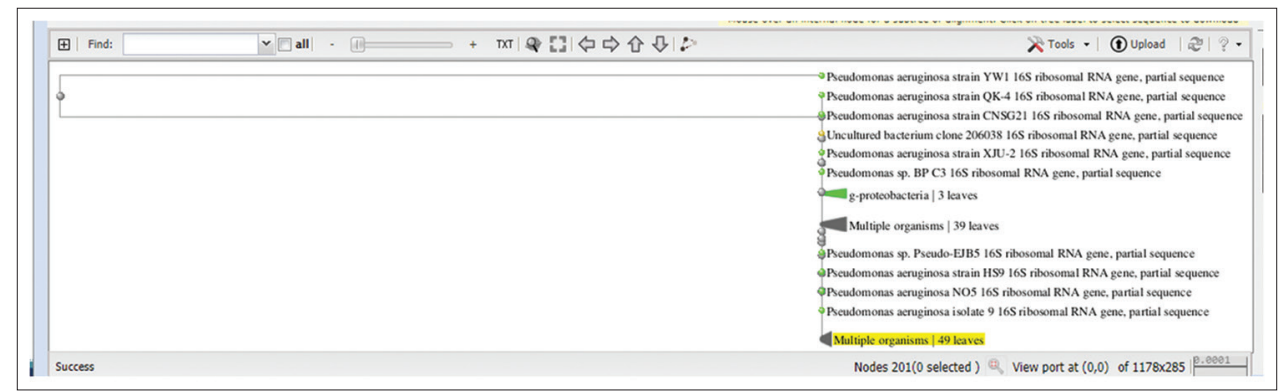

Fig. 2: Phylogenetic tree of Pseudomonas aeruginosa JBT18N

Table 3: Minimum inhibitory concentration in $\mu \mathrm{g} / \mathrm{ml}$ of pigment extract on bacterial pathogens-1. Staphylococcus aureus, 2 . Bacillus subtilis, 3. Pseudomonas aeruginosa, 4. E. coli

\begin{tabular}{|c|c|c|c|c|c|c|}
\hline S. No. & Bacterial strain & Std. - ciprofloxacin $100 \mu \mathrm{g} / \mathrm{ml}$ & $100 \mu \mathrm{g} / \mathrm{ml}$ & $200 \mu \mathrm{g} / \mathrm{ml}$ & $400 \mu \mathrm{g} / \mathrm{ml}$ & $800 \mu \mathrm{g} / \mathrm{ml}$ \\
\hline 1. & Staphylococcus aureus - ATCC 25923/MCC 2408 & $39 \mathrm{~mm}$ & - & - & - & - \\
\hline 2. & Bacillus subtilis - ATCC 6633/ MCC 2048 & $39 \mathrm{~mm}$ & - & - & - & - \\
\hline 3. & Pseudomonas aeruginosa - ATCC 27853/MCC 2080 & $39 \mathrm{~mm}$ & - & - & - & - \\
\hline 4. & Escherichia coli - ATCC 11775/MCC 2079 (T) & $40 \mathrm{~mm}$ & $17 \mathrm{~mm}$ & - & - & - \\
\hline
\end{tabular}




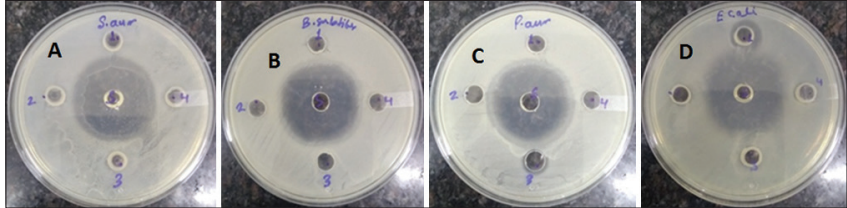

Fig. 3: Antibacterial activity of crude pigment extract from Pseudomonas aeruginosa JBT18N on A. Staphylococcus aureus, B. Bacillus subtilis, C. Pseudomonas aeruginosa, D. Escherichia. coli

$0.2 \% \mathrm{KCl}[30]$. Optimum pigment production was also found at $\mathrm{pH}-5$, $27^{\circ} \mathrm{C}$ in rotary shaker by Patil et al. [31].

The crude pigment extract was active against Escherichia coli - ATCC $11775 /$ MCC 2079 (T) at $100 \mathrm{~g} / \mathrm{ml}$ con. with $17 \mathrm{~mm}$ inhibition by KirbyBauer method, which can be compared with the similar studies carried out with pigment prodigiosin against Staphylococcus aureus, Bacillus cereus, Candida albicans, C. parapsilosis, and Cryptococcus sp. [32].

To evaluate the pigment for its cytotoxic activity against the most emerging cancer in women across the world human cervical cancer, the crude pigment extracted from the bacterial isolate in the study was assayed for its potency on HeLa cell lines and was found to be cytotoxic. A novel red pigment extracted from marine Arthrobacter sp. G20 showed moderate anticancer effects on an esophageal cancer cell line, KYSE30 [13].

\section{CONCLUSION}

Microbes serve as a choice of source for the natural therapy for various diseases. From ancient times, microbial metabolites and their derivatives have proved to be an excellent, reliable therapeutic value. Marine microbes due to their unique and versatile adaptability provide an opportunity to researchers for the discovery newer potential drugs. The present study focuses on the characterization of pigmentproducing bacteria with potential bioactive compound. Many biological active compounds are extracted from microbes so far as antibiotics, antibacterial, antifungal, anticancer, antidiabetic, and antioxidant, immunosuppressive, and so on. Microbial metabolites are so diverse in their applications that still there is lot of scope of exploring newer microbe and unique metabolite as potential drug.

\section{CONFLICTS OF INTEREST}

Authors do not have any conflicts of interest related to the manuscript.

\section{AUTHORS' CONTRIBUTIONS}

Principal author: Performed the collection of sample, designing of experiment, isolation, extraction process, and wrote the manuscript. Corresponding author supervised the work at every step and helped in evaluation of manuscript. The coauthor supported by providing infrastructure facilities and equipment to carry out the work.

\section{AUTHORS' FUNDING}

The study undertaken is completely self-funded. Authors did not receive any financial assistance from either government or non-government funding agencies.

\section{ACKNOWLEDGMENT}

The authors would like to acknowledge Karnatak University Dharwad and P.C Jabin Science College, Hubballi, for providing the laboratory facility to carry out the research. The authors would also like to acknowledge the support rendered by Cytxon Biosolutions Pvt. Ltd., Hubballi, and NCCS, Pune.

\section{REFERENCES}

1. Soliev AB, Hosokawa K, Enomoto K. Bioactive pigments from marine bacteria: Applications and physiological roles. Evid Based Complement
Altern Med 2011;2011:670349.

2. Pabba SK, Samatha B, Prasad MR, Himabindu SV. Isolation and screening of marine bacteria for antimicrobial activity along Vishakapatanam Coast. J Microbiol Biotech Res 2011;1:86-9.

3. Darshan N, Manonmani HK. Prodigiosin and its potential applications. J Food Sci Technol 2015;52:5393-407.

4. Venil CK, Zakaria ZA, Ahmad WA. Optimization of culture conditions for flexirubin production by Chryseobacterium artocarpi CECT 8497 using response surface methodology. Acta Biochim Pol 2015;62:185-90.

5. Dufossé L. Microbial production of food grade pigments. Food Technol Biotechnol 2006;44:313-21.

6. Konuray G, Erginkaya Z. Antimicrobial and antioxidant properties of pigments synthesized from microorganisms. In: Méndez-Vilas A, editor. The Battle against Microbial Pathogens: Basic Science, Technological Advances and Educational Programs. Badajoz, Spain: Formatex Research Center; 2015. p. 27-32.

7. Chen G, Shi K, Song D, Quan L, Wu Z. The pigment characteristics and productivity shifting in high cell density culture of Monascus anka mycelia. BMC Biotechnol 2015;15:72.

8. Goswami B, Bhowal J. Identification and characterization of extracellular red pigment producing bacteria isolated from soil. Int $\mathrm{J}$ Curr Microbiol Appl Sci 2014;3:169-76.

9. Subramanian P, Gurunathan J. Differential production of pigments by halophilic bacteria under the effect of salt and evaluation of their antioxidant activity. Appl Biochem Biotechnol 2019;190:391-409.

10. Cardona-Cardona V, Arroyo D, Scellekens J, Rios-Velazquez C. Characterization of blue pigmented bacteria isolated from Puerto Rico. In: Current Research, Technology and Education Topics in Applied Microbiology and Microbial Biotechnology. Badajoz, Spain: Formatex; 2010. p. 117-23.

11. Arulselvi PI, Umamaheswari S, Ranandkumar SG, Karthik C, Jayakrishna C. Screening of yellow pigment producing bacterial isolates from various eco-climatic areas and analysis of the carotenoid produced by the isolate. J Food Process Technol 2014;5:1-4.

12. Afra S, Makhdoumi A, Matin MM, Feizy J. A novel red pigment from marine Arthrobacter sp. G20 with specific anticancer activity. J Appl Microbiol 2017;123:1228-36.

13. Qureshi MA, Sankaran S, Subbaiah S. Effect of certain compounds on the pigmentation characteristis of some bacterial isolates. Int J Curr Microbiol Appl Sci 2018;7:2464-83.

14. Gallardo K, Candia JE, Remonsellez F, Escudero LV, Demergasso CS. The ecological coherence of temperature and salinity tolerance interaction and pigmentation in a non-marine Vibrio isolated from Salar De Atacama. Front Microbiol 2016;7:1943.

15. McKay CP, Rask JC, Detweiler AM, Bebout BM, Everroad RC, Lee JZ, et al. An Unusual inverted saline microbial mat community in an interdune sabkha in the Rub' al Khali (The Empty Quarter), United Arab Emirates. PloS One 2016;11:e0150342.

16. Bienhold C, Zinger L, Boetius A, Ramette A. Diversity and biogeography of bathyal and abyssal seafloor bacteria. PLoS One 2016;11:e 0148016

17. Paul D, Kumbhare SV, Mhatre SS, Chowdhury SP, Shetty SA, Marathe NP, et al. Exploration of microbial diversity and community structure of lonar lake: The only hypersaline meteorite crater lake within basalt rock. Front Microbiol 2016;6:1553.

18. Waghmare V, Kale S, Pawar K, Metri A. Isolation, identification of magnetotactic bacteria and their magnetosomes from Lonar Lake. Int $J$ Curr Res Life Sci 2018:7:1858-62

19. Nyakeri EM, Mwirichia R, Boga H. Isolation and characterization of enzyme producing bacteria from Lake Magadi, an extreme Soda Lake in Kenya. J Microbiol Exp 2018;6:57-68.

20. Rathod D, Golinska P, Wypij M, Dahm H, Rai M. A new report of Nocardiopsis valliformis strain OT1 from alkaline Lonar crater of India and its use in synthesis of silver nanoparticles with special reference to evaluation of antibacterial activity and cytotoxicity. Med Microbiol Immunol 2016;205:435-47.

21. Venil CK, Zakaria ZA, Ahmad WA. Bacterial pigments and their applications. Process Biochem 2013;48:1065-79.

22. Bana $\mathrm{M}$, Heshmatipour $Z$. Isolation of pigment-producing bacteria from surface water and study of sun protection factor (SPF) of the purified pigments. Iran J Public Health 2014;43:143.

23. Srilekha V, Krishna G, Srinivas VS, Charya MS. Antimicrobial evaluation of bioactive pigment from Salinicoccus sp isolated from Nellore Sea Coast. Int J Biotechnol Biochem 2017;13:211-7.

24. Srilekha V, Krishna G, Mahender P, Charya MS. Investigation of in vitro cytotoxic activity of pigment extracted from Salinicoccus sp. isolated from Nellore sea coast. J Mar Med Soc 2018;20:31-3. 
25. Menezes CB, Silva BP, Sousa IM, Ruiz AL, Spindola HM, Cabral E, et al. In vitro and in vivo antitumor activity of crude extracts obtained from Brazilian Chromobacterium sp isolates. Braz J Med Biol Res 2013;46:65-70.

26. Chakrabarty AM. Microorganisms and cancer: Quest for a therapy. J Bacteriol 2003;185:2683-6.

27. Newman DJ, Cragg GM. Microbial antitumor drugs: Natural products of microbial origin as anticancer agents. Curr Opin Investig Drugs 2009;10:1280-96

28. Bernardes N, Seruca R, Chakrabarty AM, Fialho AM. Microbialbased therapy of cancer. Current progress and future prospects. Bioeng Bugs 2010;1:178-90.
29. Dufosse L. Pigments, microbial. Encyclopedia Microbiol 2009; 4:457-71.

30. Asker D, Ohta Y. Production of canthaxanthin by extremely halophilic bacteria. J Biosci Bioeng 1999;88:617-21.

31. Patil S, Sivanandhan G, Thakare D. Effect of physical and chemical parameters on the production of red exopigment from Penicillium purpurogenum isolated from spoilt onion and study of its antimicrobial activity. Int J Curr Microbiol Appl Sci 2015;4:599-609.

32. Gulani C, Bhattacharya S, Das A. Assessment of process parameters influencing the enhanced production of prodigiosin from Serratia marcescens and evaluation of its antimicrobial, antioxidant and dyeing potentials. Malays J Microbiol 2012;8:116-22. 